\title{
Prognostic Value of Acute Hyperglycaemia in Non-Diabetic Acute Myocar- dial Infarction Patients
}

\author{
Authors \\ Dr Nishant Sunakarineni, Dr Veena Ramachandran \\ MBBS, MD General Medicine
}

\section{Introduction}

In recent years, much attention has been given to the evidence that the concomitant occurrence of hyperglycaemia in patients admitted to intensive care units with an acute myocardial infarction (AMI) enhances the risk of mortality and morbidity, whether the patient was diagnosed with having diabetes or not ${ }^{1}$ In some cases, the elevation of glucose levels could simply be a marker of preexisting, but not yet detected, type 2 diabetes or impaired glucose tolerance (IGT). ${ }^{2}$ This may mean that besides being causal, elevated glucose also could be a marker of existing insulin resistance and/or beta-cell failure that may contribute to the poor prognosis through other mechanisms. However, a positive association between hyperglycaemia at the time of the event and subsequent mortality from AMI has frequently been reported $^{3,4,5,6}$ A strong correlation between glycaemia and shock or development of heart failure has also been reported. ${ }^{7}$ Consequently, understanding the possible mechanisms through which hyperglycaemia worsens the prognosis of AMI, as well the effectiveness of its control during AMI, seems to be of great relevance.

It is now accepted worldwide that the most important factor influencing atherosclerotic plaque in- stability is inflammation. Elevated blood glucose levels per se adversely affect outcome through the cumulative effects of several mechanisms, including induction of endothelial dysfunction, oxidative stress, hyper coagulability and impaired fibrinolysis. ${ }^{7,8}$ Acute hyperglycaemia in healthy subjects and in patients with impaired glucose tolerance or overt diabetes produces a rise in inflammatory markers. Following this line of thought, it might be speculated that the detrimental effect of stress hyperglycaemia in acute MI might also stem from its ability to increase inflammation.

This study aims at exploring the association between the admission glycemic status and 30-day mortality in acute myocardial infarction in non diabetic patients.

\section{Materials and methods}

66 patients were included in the study and were divided into 4 groups depending on the basis of blood glucose concentration at admission, namely Group I ( $\leq 120 \mathrm{mg} \%)$,Group II (120-140 mg \%), Group III (141-167 mg \%) and Group IV (>167 $\mathrm{mg} \%$ ). The duration of the study was One year (Jan 2013-Dec 2013).

The study included all the consecutive non diabetic patients admitted to the ICCU with raised se- 


\section{JMSCR Vol||04||Issue||07||Page 11522-11526||July}

rum cardiac enzymes(CK-MB, Troponin I), any or all of symptoms suggestive of myocardial infarction for at least 30 minutes, ECG changes on at least two contiguous leads with pathological Q waves and persistent ST elevation $(>0.1 \mathrm{mV})$ who had a normal $\mathrm{HbA} 1 \mathrm{c}(<6.5)$.

The patient's cardiovascular history, medication at the time of admission, risk factors, in-hospital clinical course, including Killip's class, and the initial diagnostic and therapeutic management was recorded. Furthermore, ECG of all patients was read and recorded( STEMI, NSTEMI, Rhythm disturbances)

Subjects who were known cases of diabetes, who had received dextrose containing intravenous fluids before admission,post surgical, post trauma (up to 1 month) patients, patients receiving drugs elevating blood sugar levels. (e.g.corticosteroids), time from the beginning of symptoms to admission to the ICCU more than 48 hours,patients who had a treatment history of Oral Hypoglycaemic agents/Insulin ,patients who present with Non ST Elevation MI (NSTEMI) were excluded from the study.

The end points of study were 30 days or till death during hospitalisation. If the patient was discharged within 30 days, then appropriate follow up was done. Then comparison between the initial and 30 day-mortality data according to values of blood glucose concentrations at admission was done.
Statistical analysis methods used were Statistical Package for Social Sciences (SPSS, published SPSS Inc.) Version13, Chi- square test and one way ANOVA with post hoc test were used to identify differences between 4 groups and Bivariate correlation using Pearson's method was used to identify correlation of death as outcome.

Informed consent was taken from all the patients who participated in the study. The study was conducted as per the guidelines of the institute and approval by Ethics committee.

\section{Results}

The mean age of the patients in years was 52.11 (Group I), 56.50 (group II), 53.44 (Group III) and 62 (Group IV) respectively.

Mean systolic BP at admission was $91.90 \mathrm{~mm} \mathrm{Hg}$ in Group IV as compared to $127.78 \mathrm{~mm} \mathrm{Hg}$ in Group I, $123.33 \mathrm{~mm} \mathrm{Hg}$ in Group II and 119.13 $\mathrm{mm} \mathrm{Hg}$ in Group III. There was a statistically significant $(\mathrm{P}=0.001)$ drop in the mean systolic $\mathrm{BP}$ as we move from Group I to Group IV. The mean diastolic BP at admission was $58.50 \mathrm{~mm} \mathrm{Hg}$ in Group IV as compared to $81.11 \mathrm{~mm} \mathrm{Hg}$ in Group I, $78.33 \mathrm{~mm} \mathrm{Hg}$ in Group II and $73.50 \mathrm{~mm} \mathrm{Hg}$ in Group III.Table-1 shows that there is a statistically significant drop in the mean systolic $\mathrm{BP}(\mathrm{P}=$ $0.001)$ and mean diastolic $\mathrm{BP}(\mathrm{P}=0.01)$ as we move from Group I to Group IV. There occurred no statistically significant difference in the heart rate at admission across the groups.

Table 1-Post Hoc test: BP- Systolic and Diastolic; Significant association between Group1 and Group 2, 3 $\& 4$.

\begin{tabular}{|l|l|l|l|l|l|l|l|l|l|l|}
\hline Variable & \multicolumn{2}{|l|}{$\begin{array}{l}\text { Group 1 } \\
(\mathrm{N}=18)\end{array}$} & \multicolumn{2}{l|}{$\begin{array}{l}\text { Group 2 } \\
(\mathrm{N}=12)\end{array}$} & \multicolumn{2}{l|}{$\begin{array}{l}\text { Group 3 } \\
(\mathrm{N}=16)\end{array}$} & \multicolumn{2}{l|}{$\begin{array}{l}\text { Group 4 } \\
(\mathrm{N}=20)\end{array}$} & F & P \\
\cline { 2 - 9 } & Mean & SD & Mean & SD & Mean & SD & Mean & SD & & \\
\hline BP Systolic & 127.78 & 20.16 & 123.33 & 29.64 & 119.13 & 26.00 & 91.90 & 25.72 & 8.140 & $0.001^{*}$ \\
\hline BP Diastolic & 81.11 & 13.23 & 78.33 & 18.01 & 73.50 & 23.18 & 58.50 & 26.81 & 4.136 & $0.01^{*}$ \\
\hline Heart Rate & 88.44 & 12.24 & 82.67 & 18.63 & 88.38 & 19.21 & 79.80 & 25.78 & 0.841 & 0.477 \\
\hline
\end{tabular}




\section{JMSCR Vol||04||Issue||07||Page 11522-11526||July}

At admission, 33 patients were in Killip class I, 32 patients in Killip Class II and 1 patient in Killip class IV with no patients having Killip class III. Patients in Group III and Group IV had higher admission Killip class, which was statistically significant $(\mathrm{P}=0.029$ for number of patents with Killip class I at admission between the groups and similarly for Killip class II is $\mathrm{P}=0.025$ ). Killip class deterioration by $\geq 2$ classes during the hospital stay occurred more commonly in Groups III and IV. Killip class was high in subjects with higher admission RBS values. Statistical analysis of the number of subjects with Killip class deterioration by $\geq 2$ classes during the hospital stay among the groups showed significant difference $(\mathrm{P}=0.001)$.

Table-2 shows statistically significant difference between groups in Killip's class I \& II at admission. There is higher admission Killip's class as admission RBS value increases. This table also shows significant Killip's class deterioration by more than 2 classes during the hospital stay as admission RBS increases.

Table 2- Killip's Class association with admission RBS

\begin{tabular}{|c|c|c|c|c|c|c|c|c|c|c|}
\hline \multirow[t]{2}{*}{ Variable } & \multicolumn{2}{|c|}{$\begin{array}{c}\text { Group } 1 \\
(\mathrm{~N}=18)\end{array}$} & \multicolumn{2}{|c|}{$\begin{array}{r}\text { Group } 2 \\
(\mathrm{~N}=12)\end{array}$} & \multicolumn{2}{|c|}{$\begin{array}{c}\text { Group } 3 \\
(\mathrm{~N}=16)\end{array}$} & \multicolumn{2}{|c|}{$\begin{array}{c}\text { Group } 4 \\
(\mathrm{~N}=20)\end{array}$} & \multirow[t]{2}{*}{$\chi^{2}$} & \multirow[t]{2}{*}{$\mathrm{P}$} \\
\hline & $\mathrm{N}$ & $\%$ & $\mathrm{~N}$ & $\%$ & $\mathrm{~N}$ & $\%$ & $\mathrm{~N}$ & $\%$ & & \\
\hline Killip class I & 14 & $77.77 \%$ & 6 & $50 \%$ & 7 & $43.75 \%$ & 6 & $30 \%$ & 9.0056 & $0.029 *$ \\
\hline Killip class II & 4 & $22.23 \%$ & 5 & $\begin{array}{l}41.69 \\
\%\end{array}$ & 9 & $56.25 \%$ & 14 & $70 \%$ & 9.2868 & $0.025^{*}$ \\
\hline Killip class III & 0 & 0 & 0 & 0 & 0 & 0 & 0 & 0 & & \\
\hline Killip class IV & 0 & 0 & 1 & $8.31 \%$ & 0 & 0 & 0 & 0 & 4.5692 & 0.2061 \\
\hline $\begin{array}{l}\text { Killip class Deteoriation } \\
\text { By } \geq 2 \text { classes in the } \\
\text { hospital stay }\end{array}$ & 0 & 0 & 0 & 0 & 1 & $6.25 \%$ & 10 & $50 \%$ & 23.25 & $0.001 *$ \\
\hline
\end{tabular}

30-day mortality in our study was $5.55 \%$ in patients with Group I, compared with $16.67 \%$ in patients in Group II, $25 \%$ in Group III and $60 \%$ in Group IV. This difference in the incidence of 30- day mortality, which linearly increases as admission RBS rises, is statistically significant $(\mathrm{P}=0.0016)$.

Table 3- 30 Day Mortality and its association with admission RBS

\begin{tabular}{|c|c|c|c|c|c|c|c|c|c|c|}
\hline \multirow[t]{2}{*}{ Variable } & \multicolumn{2}{|c|}{$\begin{array}{c}\text { Group 1 } \\
(\mathrm{N}=18)\end{array}$} & \multicolumn{2}{|c|}{$\begin{array}{c}\text { Group } 2 \\
(\mathrm{~N}=12)\end{array}$} & \multicolumn{2}{|c|}{$\begin{array}{c}\text { Group } 3 \\
(\mathrm{~N}=16)\end{array}$} & \multicolumn{2}{|c|}{$\begin{array}{c}\text { Group } 4 \\
(\mathrm{~N}=20)\end{array}$} & \multirow[t]{2}{*}{$\chi^{2}$} & \multirow[t]{2}{*}{$\mathrm{P}$} \\
\hline & $\mathrm{N}$ & $\%$ & $\mathrm{~N}$ & $\%$ & $\mathrm{~N}$ & $\%$ & $\mathrm{~N}$ & $\%$ & & \\
\hline Death & 1 & $5.55 \%$ & 2 & $16.67 \%$ & 4 & $25 \%$ & 12 & $60 \%$ & 15.215 & $0.0016^{*}$ \\
\hline
\end{tabular}

\section{Discussion}

A statistically significant drop in the mean systolic $\mathrm{BP}(\mathrm{P}=0.001)$ and mean diastolic $\mathrm{BP}(\mathrm{P}=0.01)$ was noted as we move from Group I to Group IV.
Probable explanation for this is that more patients in the higher admission blood glucose groups had a lower LV ejection fraction and poorer LV function. There occurred no statistically significant 


\section{JMSCR Vol||04||Issue||07||Page 11522-11526||July}

difference in heart rate at admission across the groups. Statistical analysis showed a significant association between Killip's Class, admission RBS and Killip Class deterioration during the hospital stay. Similar result was reported by Kadri et al. ${ }^{9}$

30-day mortality increased with the rise in admission RBS which was statistically significant $(\mathrm{P}=$ 0.0016). Kadri et al reported similar findings ${ }^{9}$

Therefore the raised admission RBS is an important correlate of 30 day-mortality in our study. However we observed that it is not an independent predictor of death in our study. Probable explanation as to why higher admission glycemia was not an independent predictor of mortality, though it was a positive correlate of death in our study is, smaller sample size $(\mathrm{N}=66)$.

Several hypotheses (which are not mutually exclusive) were put forward to explain the relation between stress hyperglycemia and poor outcome. Stress hyperglycemia may be a marker of extensive myocardial damage, reflecting a surge of stress hormones such as catecholamines and cortisol that produce or augment an insulin-resistant state.10,11 Relative insulin deficiency and excess catecholamines reduce glucose uptake by the ischemic myocardium and promote lipolysis and increased circulating free fatty acids. The latter inhibit glucose oxidation (the "glucose-fatty acid cycle") and are toxic to ischemic myocardium, resulting in increased membrane damage, arrhythmias, and reduced contractility. ${ }^{12,13,14,15} \mathrm{Al}$ ternatively, elevated blood glucose levels per se adversely affect outcome through the cumulative effects of several mechanisms, including induction of endothelial dysfunction, ${ }^{16}$ oxidative stress, ${ }^{7,8}$ hypercoagulability, and impaired fibrinolysis ${ }^{9}$ Lastly, admission hyperglycemia may not be only the cause of more severe myocardial damage, but also its consequence. Large infarcts are more likely to cause catecholamine release, which affect fatty acid and glucose homeostasis.

\section{Conclusion}

Higher admission RBS was found to have lower systolic and diastolic blood pressure, higher admission Killip class with risk of $\geq 2$ classes deterioration during hospital stay and a positive linear correlation between admission RBS and 30-day mortality and therefore admission RBS is a potential indicator of hospital stay mortality in nondiabetic patients presenting with acute myocardial infarction.

\section{References}

1. Capes SE, Hunt D, Malmberg K, Gerstein HC. Stress hyperglycaemia and increased risk of death after myocardial infarction in patients with and without diabetes: a systematic overview. Lancet 2000; 355: 773778.

2. Norhammar A, Tenerz A, Nilsson G, Hamsten A, Efendíc S, Rydén L, et al. Glucose metabolism in patients with acute myocardial infarction and no previous diagnosis of diabetes mellitus: a prospective study. Lancet 2002; 359: 2140-2144.

3. Wahab NN, Cowden EA, Pearce NJ, Gardner MJ, Merry H, Cox JL. ICONS Investigators. Is blood glucose an independent predictor of mortality in acute myocardial infarction in the thrombolytic era? J Am Coll Cardiol 2002; 40: 1748-1754.

4. Stranders I, Diamant M, van Gelder RE, Spruijt HJ, Twisk JW, Heine RJ, et al. Admission blood glucose level as risk indicator of death after myocardial infarction in patients with and without diabetes mellitus. Arch Intern Med 2004; 164: 982988.

5. Wong VW, Ross DL, Park K, Boyages SC, Cheung NW. Hyperglycemia: still an important predictor of adverse outcomes following AMI in the reperfusion era. Diabetes Res Clin Pract 2004;4: 85-91.

6. Hadjadj S, Coisne D, Mauco G, Ragot S, Duengler F, Sosner P, et al. Prognostic value of admission plasma glucose and 


\section{JMSCR Vol||04||Issue||07||Page 11522-11526||July}

HbA1c in acute myocardial infarction. Diabet Med 2004; 1: 05-310.

7. Zeller M, Cottin Y, Brindisi MC, Dentan G, Laurent Y, Janin-Manificat L, et al. Impaired glucose and cardiogenic shock in patients with acute myocardial infarction. Eur Heart J 2004; 355: 308-12.

8. Antman EM, Selwyn AP, Braunwald E, Loscalzo J. Ischemic Heart Disease. In Harrison's Principles of Internal Medicine. Editors: Fauci AS, Braunwald E, Kasper DL, Hauser SL, Longo DL, Jameson JL, Loscalzo J. 18th edition. Mc Graw Hill. Vol 2. 1998-2035.

9. Kadri Z, Danchin N, Vaur L, Cottin Y, Gueret P, Lablanche JM, et al. Major impact of admission glycemia on 30 day and one year mortality in non diabetic patients admitted for myocardial infarction:results from the nationwide French USIC 2000 study. Heart 2006; 92: 910-915.

10. Oswald GA, Smith CC, Betteridge DJ, Y udkin JS. Determinants and importance of stress hyperglycemia in non diabetic patients with myocardial infarction. BMJ 1986; 293: 917-22.

11. Oswald GA, Smith CC, Delamothe AP, Betteridge DJ, Yudkin JS.Raised concentrations of glucose and adrenaline and increased in vivo platelet activation after myocardial infarction. Br Heart J 1988; 59: 663-671.

12. Oliver MF, Kurien VA. Serum-free-fattyacids and arrhythmias after acute myocardial infarction. Lancet 1969; 2: 10771078.

13. Lopaschuk GD, Stanley WC. Glucose metabolism in the ischemic heart. Circulation 1997; 95: 313-315.
14. Taegtmeyer H, McNulty P, Young ME. Adaptation and maladaptation of the heart in diabetes, part I: general concepts. Circulation 2002; 105: 1727-1733.

15. Depre C, Vanoverschelde JL, Taegtmeyer H. Glucose for the heart.Circulation 1999; 99: $578-588$.

16. Ceriello A, Giugliano D, Quatraro A, Dello Russo P, Torella R. Blood glucose may condition factor VII levels in diabetic and normal subjects. Diabetologia 1988; 31: 889-891. 